\title{
Natural and experimentally induced lesions of the body wall of the sea urchin Strongylocentrotus droebachiensis
}

\author{
Debra L. Roberts-Regan*, Robert E. Scheibling, Joanne F. Jellett \\ Biology Department, Dalhousie University, Halifax, Nova Scotia, Canada B3H 4J1
}

\begin{abstract}
Lesions of the body wall occurred in about $7 \%$ of sea urchins Strongylocentrotus droebachiensis in a healthy population off Nova Scotia, Canada. Lesions occurred predominantly in the oral hemisphere in both ambulacral and interambulacral areas. On average, lesions covered 8 to $12 \%$ of the total test surface of individuals, although lesion size was quite variable. Lesioned areas of test generally were darkly pigmented, covered with a mucoid layer, and devoid of spines, pedicellariae and tube feet. Three morphological types of lesions were identified, which appeared as progressive stages: Stage 1 with a thin mucoid layer, nearly transparent to pinkish in coloration; Stage 2 with a thick more darkly pigmented mucoid layer, ranging from reddish to purplish-black; and Stage 3 with spine regeneration through a pigmented mucoid layer. The test in lesioned areas was often friable, but rarely perforated. Scanning electron microscopy indicated extensive degeneration of the epidermis and stereom. Gonads of lesioned individuals were frequently discoloured, but gonad sizes were not significantly different between healthy and lesioned individuals. Microflora normally found on healthy body surfaces of the sea urchin proliferated in lesioned areas. Of 85 isolates identified from swab samples of lesioned and healthy test surfaces, $93 \%$ were Gram-negative bacteria belonging mainly to the taxa Acinetobacter, Alcaligenes, Flavobacterium, Pseudomonas and Enterobacteriaceae. The total number of microorganisms and the numbers of Acinetobacter and Alcaligenes were significantly higher on lesioned surfaces (Stage 1 or Stage 2) than on healthy surfaces of the same individuals. Most bacterial types increased in abundance from Stage 1 to Stage 2 lesions, although this increase was statistically significantly only for Acinetobacter. Vibrionaceae, Gram-positive bacteria and fungi occurred sporadically and in low abundance on lesioned and healthy test surfaces. Mechanical abrasion of the test surface of the sea urchin produced lesions similar in gross morphology to naturally occurring ones. In laboratory experiments, lesions developed in all abraded individuals, irrespective of exposure to lesioned or healthy conspecifics either by a waterborne route or by direct contact. Lesion development was accelerated, and recovery retarded, by directly contacting the abraded test surface with material from a natural lesion. Unabraded sea urchins did not develop lesions indicating that removal of the epidermis provides a route of infection. Rate of recovery of experimentally abraded individuals (as measured by spine regeneration and reduction in lesion size) was significantly higher at $16^{\circ} \mathrm{C}$ than at $3^{\circ} \mathrm{C}$. Provision of food (kelp) had a significant positive effect on recovery after $12 \mathrm{wk}$. Body wall lesions of $S$. droebachiensis appear to be symptoms of chronic, superficial infections from which sea urchins generally recover. The increased incidence of lesions in this species (and others) during or after outbreaks of acute disease may reflect secondary bacterial and/or fungal infections.
\end{abstract}

\section{INTRODUCTION}

Body wall lesions, consisting of necrotic areas of test devoid of spines, pedicellariae and tube feet, are commonly observed in sea urchins, particularly in association with mass mortality events (Johnson 1971a, b,

- Present address: Park View Education Centre, Bridgewater, Nova Scotia, Canada B4V 1C4
Pearse et al. 1977, Pearse \& Hines 1979, Bourdouresque et al. 1981, Hobaus et al. 1981, Miller \& Colodey 1983, Lessios et al. 1984, Maes \& Jangoux 1984, Scheibling \& Stephenson 1984, Gilles \& Pearse 1986). Maes \& Jangoux (1984) attribute such lesions to what they collectively term the 'bald-sea-urchin disease'. Bacterial infections are generally thought to be the cause of lesions (Maes \& Jangoux 1984, 1985, Gilles \& Pearse 1986), although a variety of microorganisms (e.g. 
ciliates) have been observed on lesioned surfaces (Johnson 1971a, Maes \& Jangoux 1985, Gilles \& Pearse 1986, Maes et al. 1986). Lesions can be induced in sea urchins through abrasion of the body wall and inoculation of the injured area with lesion material or bacteria isolated from lesions (Maes \& Jangoux 1984, 1985, Gilles \& Pearse 1986, Maes et al. 1986). Sea urchins treated in this manner generally develop lesions within a few days which heal within 3 to 4 mo (Maes \& Jangoux 1984, Gilles \& Pearse 1986).

Lesions, similar in gross morphology to those described for other sea urchins, are usually in low incidence in populations of the green sea urchin Strongylocentrotus droebachiensis off Nova Scotia, Canada (Scheibling \& Stephenson 1984, Miller 1985). Mass mortality of $S$. droebachiensis between 1980 and 1983 (Miller \& Colodey 1983, Scheibling 1984, 1986, Scheibling \& Stephenson 1984) have been attributed to an amoebic disease characterized by progressive loss of muscle function in tube feet, spines and mouth, and eventual spine loss (Jones \& Scheibling 1985, Jones et al. 1985). Although discrete lesions do not appear to be symptomatic of the amoebic disease, the incidence of lesions increases following outbreaks of this disease suggesting secondary infection (Scheibling \& Stephenson 1984).

In this study we describe lesions of Strongylocentrotus droebachiensis and examine the microbiota associated with lesioned and healthy areas of test. Also, we experimentally investigate the transmission of lesions of $S$. droebachiensis and the effects of temperature and food availability on the rate of recovery of lesioned individuals. Our results are compared to previous findings with other sea urchin species to provide further insights into the dynamics of these infections and their ecological significance.

\section{MATERIALS AND METHODS}

Collection and measurement of specimens. Strongylocentrotus droebachiensis were collected from Sandy Cove, Nova Scotia $\left(44^{\circ} 30^{\prime} \mathrm{N}, 66^{\circ} 07^{\prime} \mathrm{W}\right)$ in June 1984 and January 1985. Lesioned and healthy individuals were maintained without food in separate $250 \mathrm{l}$ tanks supplied with flowing ambient seawater.

The horizontal test diameter of lesioned individuals and the size of their lesions (length $x$ width) were measured ( $1 \mathrm{~mm}$ accuracy), and the location of the lesions on the test surface was recorded. Total test area ( $\mathrm{TA}, \mathrm{cm}^{2}$ ) was estimated from horizontal test diameter (HTD, mm) by the regression equation $\mathrm{TA}=2.89 \mathrm{HTD}$ - $87.89\left(n=20 ; r^{2}=0.91\right)$ for the size range of sea urchins used (40 to $70 \mathrm{~mm}$ diameter). Test area for the regression was estimated by tracing an area equivalent to $1 / 10$ of the total test area (along an ambulacral field) onto paper. The area of the tracing was calculated from the weight (by relating it to the weight of a known area of paper) and multiplied by 10 . Lesion size was expressed as percentage of total test area.

Gonad index (gonad dry weight expressed as percentage of total dry weight) was measured for healthy and lesioned individuals (50 to $60 \mathrm{~mm}$ diameter) collected in January 1985. Gonads were examined for gross abnormalities.

Microbiological procedures. For microbiological study, lesioned and healthy sea urchins, collected in January 1985, were transported to the laboratory within $4 \mathrm{~h}$ in separate insulated coolers. Immediately upon arrival at the laboratory, 2 groups of 5 lesioned individuals were selected based un qualitative differences in the gross morphology of their lesions (Stage 1 and Stage 2; see 'Results'). Lesioned and/or healthy areas of test (ca $1 \mathrm{~cm}^{2}$ ) from each of the lesioned individuals and from 5 healthy non-lesioned individuals were uniformly swabbed for Gram staining and plating on a general growth medium for marine microorganisms, LIB-X agar (Baross et al. 1974) in artificial seawater $(3.8 \% \mathrm{w} / \mathrm{v}$ RILA Salts Mix, Rila Products Co., Teaneck, NJ, USA).

After $72 \mathrm{~h}$ growth at $20^{\circ} \mathrm{C}$ in LIB-X media, isolated bacterial colonies were characterized by size, colour, margin, elevation, surface texture and optical properties. Colonies of each type were counted in the swabbed area on each plate. Confluent growth of some types occurred on a few plates and was assigned a conservative estimate of 100 colony forming units (CFU) for purposes of statistical analysis. Each bacterial type was subcultured and isolated on LIB-X agar. After $72 \mathrm{~h}$ growth, each type was suspended in 2 storage media, tryptic soy broth and skim milk, with $15 \%$ glycerol, and frozen at $-70^{\circ} \mathrm{C}$ until biochemical characterization.

Bacteria from frozen samples were regrown on LIB-X agar at $20^{\circ} \mathrm{C}$ for $72 \mathrm{~h}$. Gram stain preparations from isolated colonies were examined for cellular morphology. Bacteria were characterized with the API system which consists of a strip of 20 miniaturized biochemical tests (API Laboratory Products Ltd., St. Laurent, Quebec, Canada). A dilute bacterial suspension in artificial seawater was added to either a fermentative (API 20E) or non-fermentative (Rapid NFT) API strip depending upon the results of initial cytochrome oxidase (API), and oxidative/fermentative and motility tests (Walters \& Plumb 1978). Before using fermentative API strips, $0.7 \mathrm{ml}$ of $20 \% \mathrm{NaCl}$ were added to the basal medium prior to the addition of the bacterial suspension to increase the salt concentration to $2.85 \%$, suitable for the growth of marine bacteria. Bacterial suspensions for other tests were made up in $0.2 \mu \mathrm{m}$ filtered natural seawater that was aged for 3 yr. 
Tables 1 and 5 in Gibson et al. (1976) and Bergey's Manual of Systematic Bacteriology (Holt 1984) were used to classify bacteria to family based on bacterial cellular and colony morphological characteristics and biochemical test results.

Light and scanning electron microscopy. Lesioned and healthy areas of test from 5 individuals were examined by light and scanning electron microscopy. Small pieces of test (approximately $2 \mathrm{~cm}^{2}$ ) were removed with sterile scissors, fixed for $24 \mathrm{~h}$ in cold $2.5 \%$ gluteraldehyde in artificial seawater, and then transferred to $0.1 \mathrm{MNa}$ caocodylate buffer at $4{ }^{\circ} \mathrm{C}$ until further processing. Samples for light microscopy $\left(0.5 \mathrm{~cm}^{2}\right)$ were decalcified (1 to $\left.2 \mathrm{wk}\right)$ in $10 \%$ EDTA (ethylenediaminetetra-acetic acid) adjusted to $\mathrm{pH} 6.8$ at room temperature, transferred to cold sterile artificial seawater for storage at $4{ }^{\circ} \mathrm{C}$, dehydrated stepwise in acetone, cleared in xylene, and embedded in paraffin. Blocks were sliced at 7 to $10 \mu \mathrm{m}$. Sections were stained in Brown and Brenn stain for bacteria in tissue, mounted with Permount and viewed under oil at $1000 \times$ magnification. Samples for scanning electron microscopy $\left(0.5 \mathrm{~cm}^{2}\right)$ were postfixed for $1 \mathrm{~h}$ in $1 \% \mathrm{OsO}_{4}$ in $0.1 \mathrm{MNa}$ caocodylate buffer at $4{ }^{\circ} \mathrm{C}$, dehydrated stepwise in acetone (while gradually letting samples warm up to room temperature), critical-point dried, and coated with gold paladium.

Transmission experiment. To investigate the transmission of infectious agents responsible for lesion formation, healthy individuals 40 to $60 \mathrm{~mm}$ in horizontal test diameter were exposed to water flowing over lesioned conspecifics or contacted with material swabbed from a lesion. To investigate the effect of abrasion of the body wall on transmission, half of the exposed individuals (waterborne or contact exposure) were mechanically abraded. A sterile scalpel was used to remove the epidermis, tube feet, spines and pedicellaria from an area approximately $1.5 \mathrm{~cm} \times$ $1.5 \mathrm{~cm}$ on the equator of the test, extending over both interambulacral and ambulacral areas. For each type of exposure treatment, 10 non-abraded and 10 abraded individuals were placed in separate halves of a $44 \mathrm{l}$ glass aquarium divided by a perforated barrier. For waterborne exposure, 5 lesioned individuals were placed in a plexiglass tube spliced into the incurrent seawater line supplying the experimental individuals as described by Scheibling \& Stephenson (1984). Another tube containing 5 healthy individuals was spliced into the line supplying a control group of sea urchins. For direct contact exposure, experimental individuals were innoculated with material transferred from lesions of field-collected individuals with a sterile cotton swab. All treatment groups were maintained at $14^{\circ} \mathrm{C} \pm 0.5^{\circ} \mathrm{C}$ in a temperature controlled, flowthrough sea water system under a $12: 12 \mathrm{~h}$ light-dark cycle. Sea urchins were examined daily for $4 \mathrm{wk}$ and macroscopic changes in surface texture and pigmentation of lesions were recorded.

Recovery experiment. To investigate the effects of temperature and food availability on the recovery of lesioned individuals, groups of 10 sea urchins with artificially induced lesions were exposed to each combination of 2 temperatures $\left(16 \pm 0.5^{\circ} \mathrm{C} ; 3 \pm 1^{\circ} \mathrm{C}\right)$ and 2 feeding regimes (fed; unfed) in the seawater system described above. Controls consisted of groups of 10 healthy sea urchins exposed to the same treatment combinations. Individuals in each group were maintained singly in cylindrical plastic mesh containers ( $8 \mathrm{~cm}$ diameter, $13 \mathrm{~cm}$ height, $1.1 \mathrm{~mm}$ mesh aperture) suspended in a $44 \mathrm{l}$ aquarium supplied with flowing seawater. Sea urchins in $16^{\circ} \mathrm{C}$ treatments were acclimated stepwise by $4^{\circ} \mathrm{C}$ increments over $1 \mathrm{wk}$ at the onset of the experiment. Fed individuals each were provided with a $13 \mathrm{~cm} \times 2 \mathrm{~cm}$ section of kelp blade Laminaria longicruris at 2 to $3 \mathrm{~d}$ intervals. In a concurrent experiment, recovery was monitored in 2 groups of 10 field-collected sea urchins, with lesions ranging in size from 1 to $30 \mathrm{~cm}^{2}$ ( 2 to $34 \%$ of the test area), that were maintained in the same seawater system (in separate aquaria) at 3 and $16^{\circ} \mathrm{C}$ and not fed.

Changes in size and gross morphology of lesioned areas were monitored by tracing lesions onto a transparent acetate sheet. Surface area of each lesion was measured from tracings using a computer digitizing program. Tracings were made at 2 to $3 \mathrm{~d}$ intervals during the first week when lesion development was rapid, and at 2 to 3 wk intervals thereafter for a period of $12 \mathrm{wk}$. The horizontal test diameter and the time required for an individual to right itself when inverted were measured before and after the experiment. All individuals were dissected at the termination of the experiment for internal examination.

\section{RESULTS}

\section{Description of lesions from field-collected individuals}

The incidence of lesioned individuals in the sea urchin population at Sandy Cove was about $7 \%$ in both June $1984(n=975)$ and January $1985(n=775)$. Lesion size ranged from a few $\mathrm{mm}^{2}$ to greater than half the total test surface area. The mean ( \pm standard deviation) percentage of the test surface area covered by lesions was $7.6 \pm 13.3 \%(n=61)$ in June 1984 and $12.0 \pm 14.1 \%(n=49)$ in January 1985 . There was no correlation between lesion size and test diameter $\left(r^{2}=\right.$ $0.029, n=50$ ). Lesions occurred mainly on the oral and lateral regions of the test and in both the ambulacral and interambulacral regions (Table 1) 
Lesioned areas of the sea urchin test were generally darkly pigmented, covered with a mucoid layer, and devoid of spines, pedicellariae and tube feet. The test in lesioned areas was often friable but rarely perforated. Considerable variation existed in the gross morphology of these lesions, although distinct types could be identified: Stage 1 lesions had a thin mucoid layer that was nearly transparent to pinkish in coloration (Fig. 1a); Stage 2 lesions had a thicker layer that was more darkly pigmented, ranging from reddish to purplish black (Fig. 1b). Individuals often had lesions with characteristics of both stages. These 2 types were designated as stages in accordance to the sequence of lesion development observed in laboratory experiments (see below).

Distinct morphological differences in test structure between lesioned (Stage 2) and healthy individuals were consistently observed by scanning electron microscopy. Micrographs of lesioned test surfaces indicated a disaggregated epidermal layer with particulate debris, bacteria, and coelomocytes (Fig. 2a). Healthy test surfaces had an intact epidermal layer, generally devoid of surface debris and extraneous cells (Fig, 2b). Micrographs of cross-sections of lesions and of healthy test surfaces indicated a predominance of fibrous material, probably collagen, in lesioned areas (Fig. 2c) in contrast to the highly organized stereom of nonlesioned areas (Fig. 2d). The presence of aggregations of red spherule cells on lesioned but not on healthy sections of decalcified test was the only conspicuous difference observed by light microscopy.

Atrophied gonads were observed in $65 \%$ of lesioned individuals $(n=20)$ collected from Sandy Cove in January 1985 . Gonads were dark brown to black in colour and shrunken in appearance. Internal test areas adjacent to discoloured gonads also were discoloured. No other tissues appeared to be affected. Gonadal abnormalities were not observed in healthy individuals. The mean gonad index of lesioned individuals $(4.9 \pm 2.8$, $n=20)$ was less than that of healthy individuals $(7.4 \pm$ 2.7, $n=20$ ) but the difference was not statistically significant.

\section{Microbiota of lesions}

Qualitative differences between lesioned and healthy test areas were evident from Gram stain preparations. Material swabbed from healthy test areas (of either non-lesioned or lesioned individuals) contained few bacteria and little mucoid material. In contrast, material swabbed from lesioned test surfaces was characterized by large amounts of mucoid materials, debris, sea urchin coelomocytes (e.g. red spherule cells) and conspicuous clumps of bacteria.

In total, 85 isolates were identified from swab samples of all test surfaces. $93 \%$ of isolates were Gramnegative bacteria, $3.5 \%$ were Gram-positive bacteria (rods and cocci), and $3.5 \%$ were fungi. The total abundance of microorganisms from Stage 1 or Stagc 2 lesions was significantly higher than that from healthy areas of the same individual (1-tailed paired sign test, $p<0.025$ ) (Fig. 3). The abundance of microorganisms obtained from Stage 2 lesions was not significantly different than that obtained from Stage 1 lesions (Mann-Whitney $U$-test, $p>0.05$ ). There was no significant difference in the abundance of microorganisms obtained from healthy test areas among lesioned (Stage 1 and Stage 2) and non-lesioned individuals (Kruskal-Wallis test, $p>0,10$ ).

Gram-negative bacteria commonly isolated from both healthy and lesioned test surfaces were non-fermentative and included Acinetobacter, Alcaligenes, Flavobacterium, Pseudomonas and Enterobacteriaceae. The abundance of both Acinetobacter and Alcaligenes from Stage 1 and Stage 2 lesions was significantly higher than from healthy areas of test from the same individuals (1-tailed paired sign test, $p$ $<0.025)$. The abundance of Acinetobacter from Stage 2 lesions (all 5 samples yielded confluent growth) was significantly higher than from Stage 1 lesions (Mann Whitney $U$-test; $p=0.005$ ). The abundance of Alcaligenes did not differ significantly between Stage 1 and Stage 2 lesions. Confluent growth of Alcaligenes was observed in 2 of the 5 samples from Stage 2 lesions, but the remaining 3 samples had between 0

Table 1 Strongylocentrotus droebachiensis. Absolute and percentage (in parentheses) frequency of occurrence of lesions in aboral, lateral and oral regions of the test and in ambulacral and interambulacral regions for sea urchins from Sandy Cove, Nova Scotia, Canada. Cumulative percentages exceed $100 \%$ as some lesions extended over 2 adjacent regions. Aboral, lateral and oral regions are defined as areas of the test bounded by the upper, central and lower one third respectively of the aboral-oral axis

\begin{tabular}{|c|c|c|c|c|c|c|}
\hline \multirow[t]{2}{*}{ Date } & \multicolumn{3}{|c|}{ Horizontal regions } & \multicolumn{2}{|c|}{ Longitudinal regions } & \multirow{2}{*}{$\begin{array}{c}\text { Number o } \\
\text { lesions }\end{array}$} \\
\hline & Aboral & Lateral & Oral & Ambulacral & Interambulacral & \\
\hline June 1984 & $9(12)$ & $26 \quad(34)$ & $54(71)$ & $39(51)$ & 71 (93) & 76 \\
\hline January 1985 & $7(11)$ & $46(68)$ & $44(65)$ & $57\{84\}$ & $61(90)$ & 68 \\
\hline Total & $16(11)$ & $72(50)$ & $98(68)$ & $96(67)$ & $132(92)$ & 144 \\
\hline
\end{tabular}



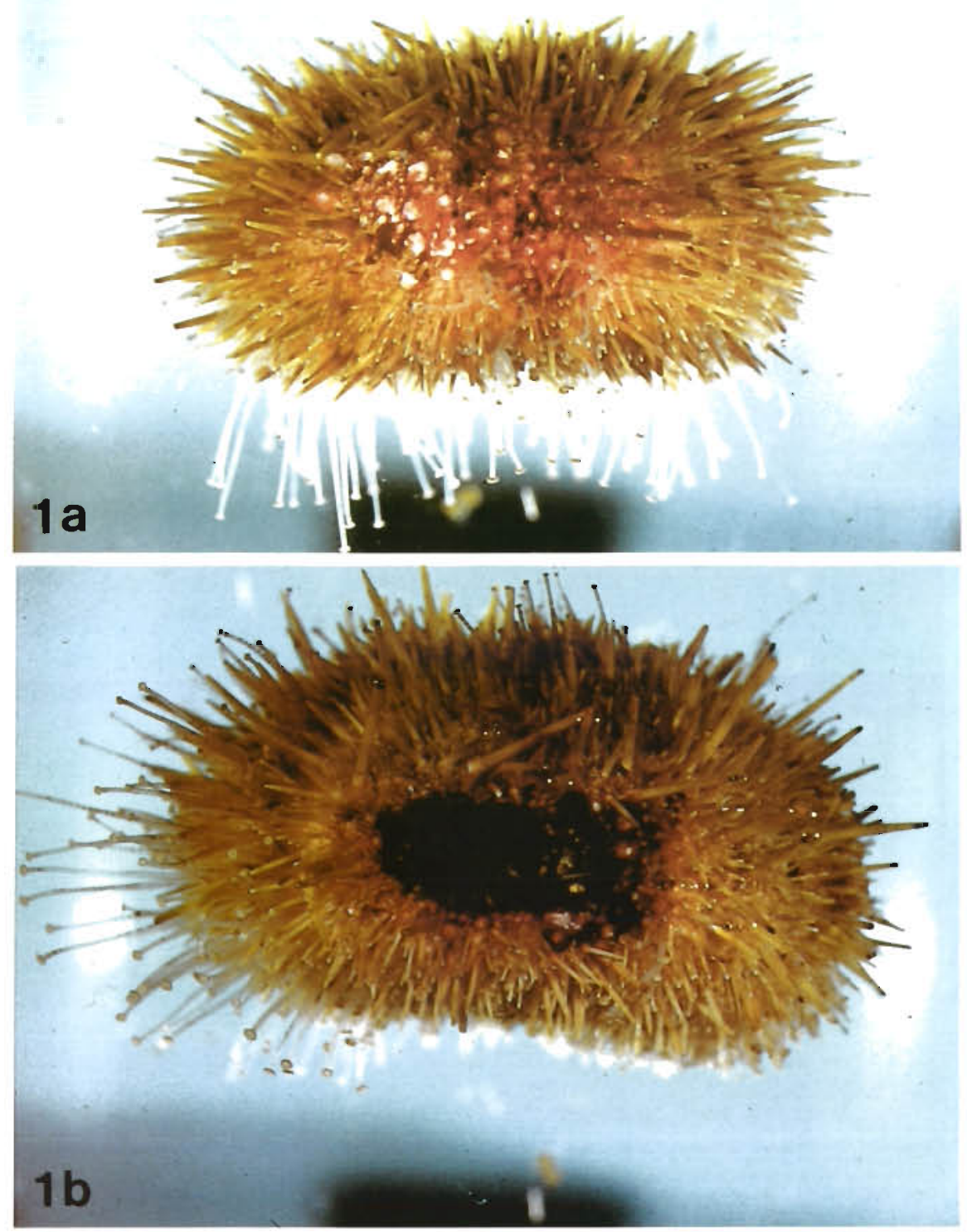

Fig. 1. Lesions of Strongylocentrotus droebachiensis. (a) Stage 1 lesion (field-collected individual): test area devoid of external appendages and covered with a thin, lightly pigmented mucoid layer. (b) Stage 2 lesion (field-collected individual): test area devoid of external appendages and covered with a thick, darkly pigmented mucoid layer (c) Stage 3 lesion (experimental individual): spine regrowth around a remaining lesioned area

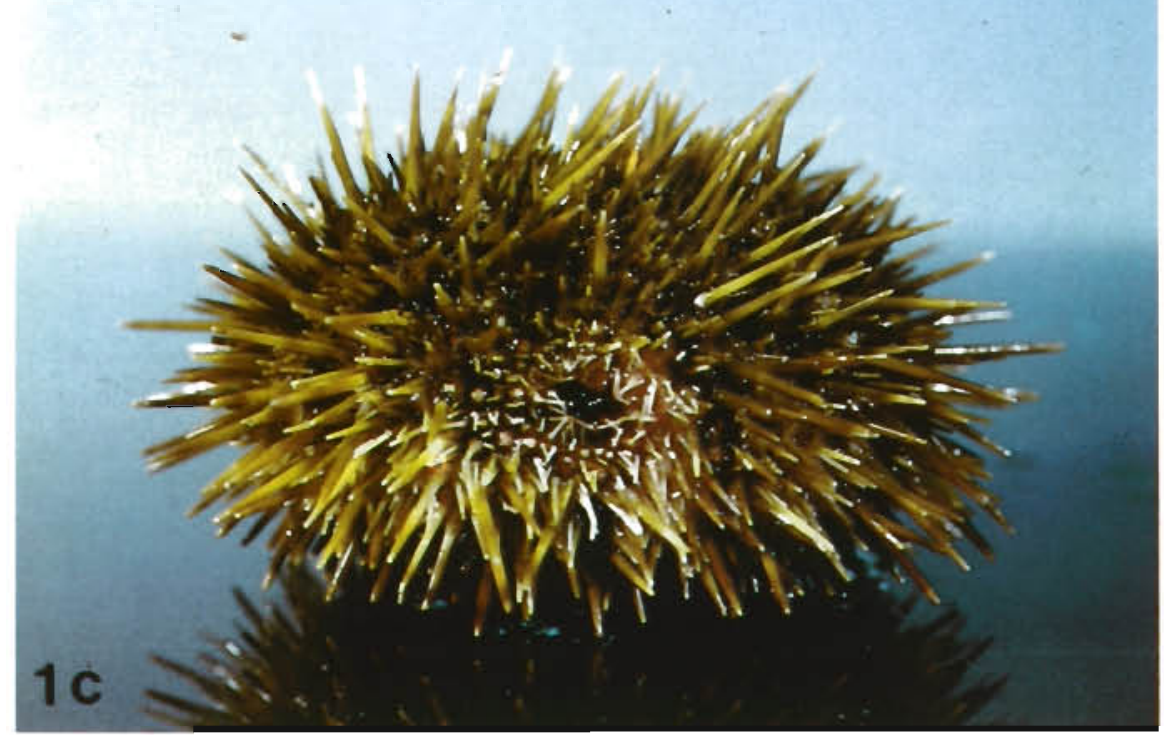



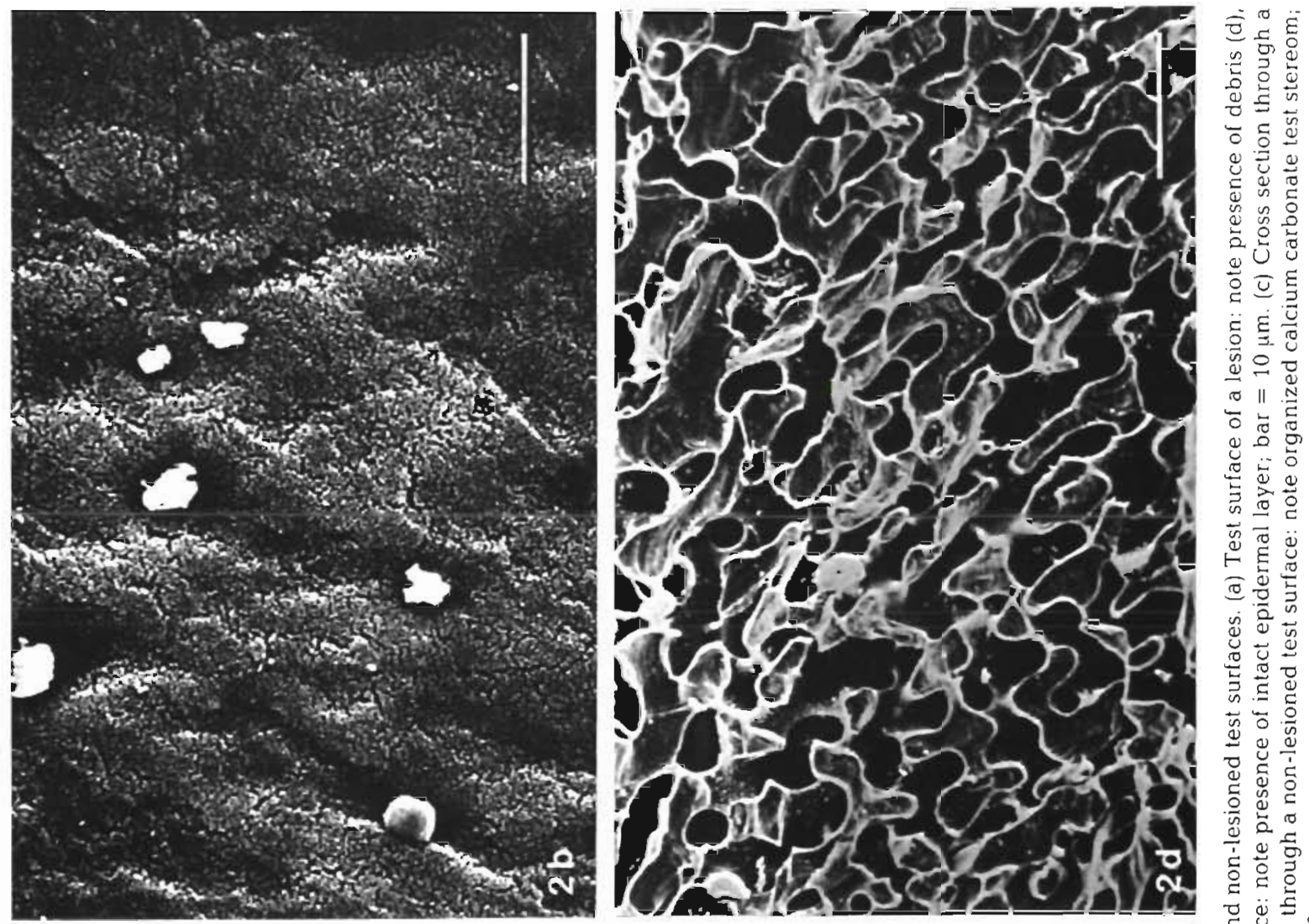

(1) $2 x^{2}$

1400

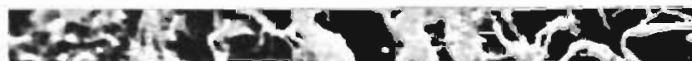

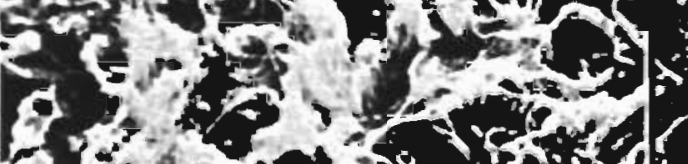

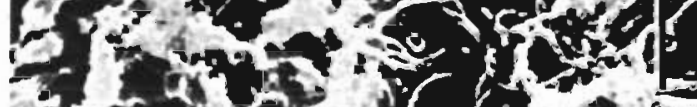

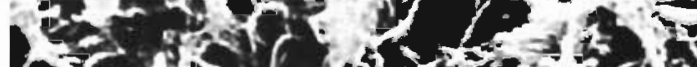

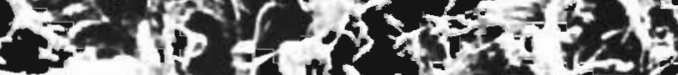

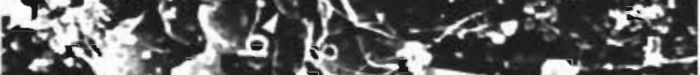

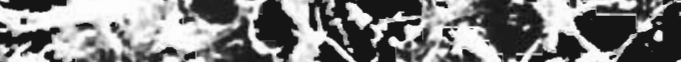

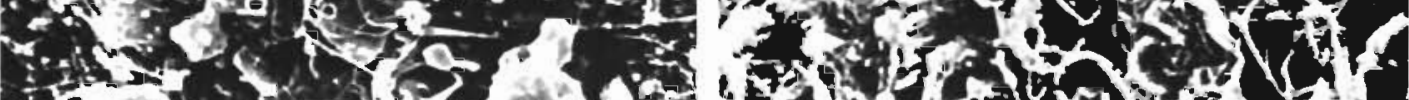
3
4 ¿

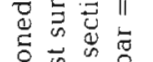


Fig. 3. Strongylocentrotus droebachiensis. Abundance of microorganisms (as colony forming units, $\mathrm{CFU}$, in swabbed area of a plate) in swabbed samples from healthy test $(\mathrm{H})$ of nonlesioned sea urchins and healthy test $(\mathrm{H})$ and lesioned test (L) of lesioned (Stage 1 and Stage 2) sea urchins Bars are means, vertical lines are standard error $(n=5)$. Arrows indicate that 1 or more samples yielded confluent growth of bacterial colonies of this type of microorganism, which was conservatively estimated as 100 CFU (i.e. means are conservative and no standard errors are given for these samples)

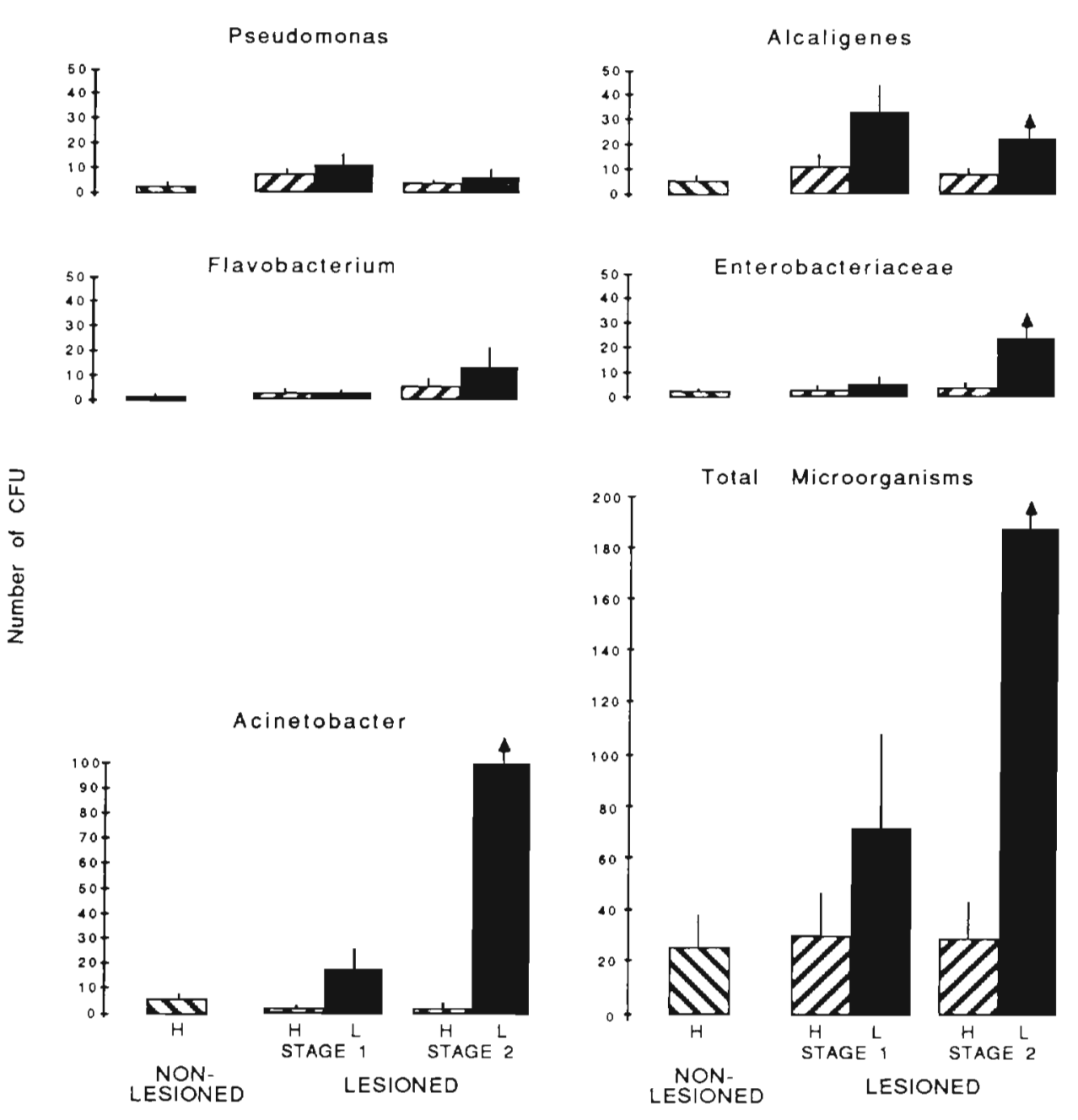

$\vec{J}$
U
$\overline{0}$
$\bar{d}$
$\stackrel{0}{E}$
$\bar{z}$

Microorganisms

Alcaligenes

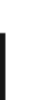

and 8 colony forming units (CFU). Abundances of Flavobacterium, Pseudomonas and Enterobacteriaceae were not significantly different between lesioned and healthy areas of test (Wilcoxon's signed rank test, $p$ $>>0.05$ ). For each of the above bacterial taxa, there was no significant difference in abundance from healthy test areas among lesioned (Stage 1 and Stage 2) and non-lesioned individuals (Kruskal-Wallis test, $p>0.10$ ). Vibrionaceae, Gram-positive bacteria and fungi from both healthy and lesioned test surfaces occurred sporadically in very low abundance $(<2 \mathrm{CFU})$ and were not analyzed statistically.

\section{Progression of artificially induced lesions}

In laboratory experiments, mechanical abrasion of the test surface was necessary to induce lesions; lesions did not develop in any unabraded individuals. Lesions induced in this manner were similar in gross morphology to those described for field-collected individuals. A thin, lightly pigmented mucoid layer (Stage 1) formed over the abraded area within $2 \mathrm{~d}$. The lesion subsequently became covered with a thick, darkly pigmented mucoid layer (Stage 2) which spread from the central region to the periphery, where it often formed a ridged border with the surrounding healthy test. Stage 1 conditions generally reappeared around the periphery of the lesion. Spine regeneration and healing (Stage 3, Fig. 1c) occurred along the periphery and proceeded towards the central area so that the lesion progressively decreased in size.

Lesion progression was most rapid when the abraded surface was innoculated with material swabbed from the lesion of a field-collected individual (Fig. 4). The rate of lesion progression was similar for individuals exposed to water flowing past lesioned or healthy conspecifics (Fig. 4). Recovery of the lesioned area, characterized by spine regeneration, was slowest for individuals directly contacted with lesion material. Only $50 \%$ of contacted individuals showed spine regrowth after $4 \mathrm{wk}$, whereas all non-contacted individuals showed spine regrowth at this time (Fig. 4).

The rate of recovery of lesioned individuals under 


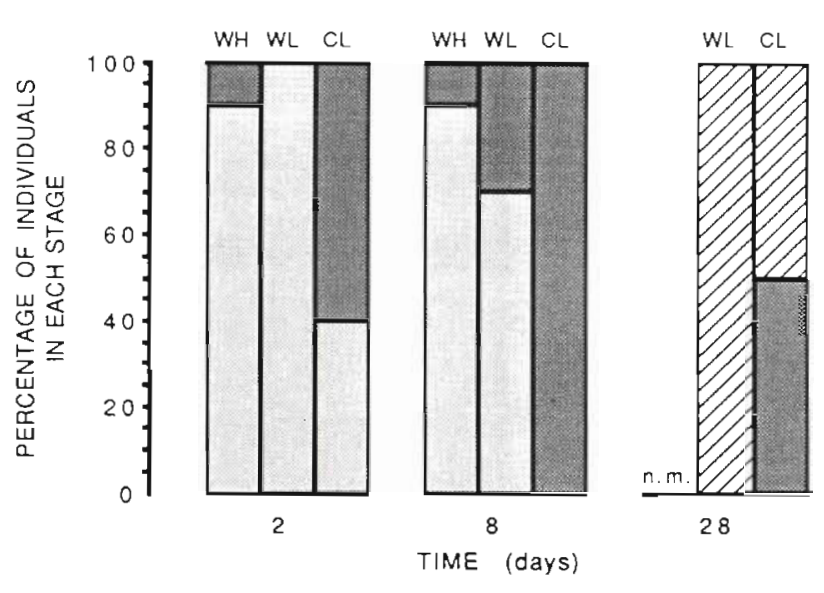

Fig. 4. Strongylocentrotus drnehachiensis. Development of lesions in abraded individuals ( $n=10$ per treatment) held under the following treatment conditions over a $28 \mathrm{~d}$ period at $14^{\circ} \mathrm{C}$ : WH, waterborne exposure to healthy individuals (not

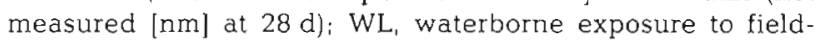
collected lesioned individuals; $\mathrm{CL}$, direct contact with lesion material. Light shading, dark shading and hatching represent lesion Stages 1, 2, and 3 respectively (see Fig. 1)

different conditions of temperature and food supply was measured both by the incidence of spine regeneration (Fig. 5a) and by the relative change in lesion area (Fig. 6). A log-linear contingency table analysis at $6 \mathrm{wk}$ indicated that temperature had a significant effect $(p<0.05)$ on the incidence of spine regeneration: all lesioned individuals at $16^{\circ} \mathrm{C}$ had regenerated spines by this time. After $12 \mathrm{wk}$, neither food or temperature had a significant effect on the incidence of spine regeneration. One individual in each treatment at $16^{\circ} \mathrm{C}$ reverted from Stage 3 to Stage 2 during the course of the experiment.

Mean lesion size increased in all treatments during the first $6 \mathrm{wk}$ of the experiment (Fig. 6). At $6 \mathrm{wk}$, the relative increase in the lesion area (percentage of initial abraded area) was significantly higher at 3 than at $16^{\circ} \mathrm{C}(2$-way ANOVA, $p<0.001)$. Food availability did not have a significant effect on the relative change in lesion area $(p=0.773)$ and there was no significant interaction between food availability and temperature $(p=0.612)$. Although mean lesion size decreased between 6 and $12 \mathrm{wk}$ in all treatments, it remained larger than the initial size in all but in the $16^{\circ} \mathrm{C}$ fed treatments. The effects of temperature $(p<<0.001)$ and food availability $(p=0.013)$ were significant at $12 \mathrm{wk}$, but there was no significant interaction between the 2 factors $(p=0.336)$. In one individual in each of the $3^{\circ} \mathrm{C}$ treatments and in 2 individuals in the $16^{\circ} \mathrm{C}$ fed treatment the lesions rapidly expanded in size culminating in death before the end of the experiment. These individuals were omitted from the statistical analysis. No control sea urchins developed lesions or died during the experiment.
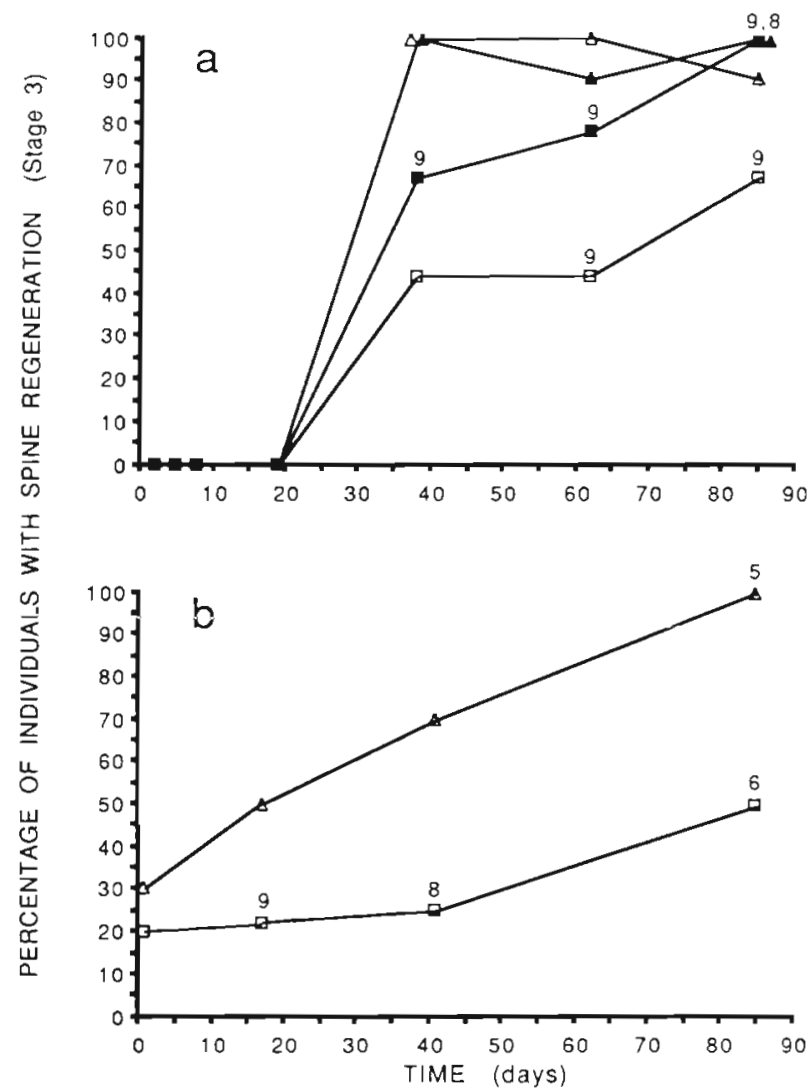

Fig. 5. Strongylocentrotus droebachiensis. Percentage of individuals with spine regeneration in (a) experimentally abraded individuals and (b) field-collected lesioned individuals over an $85 \mathrm{~d}$ period at $3^{\circ} \mathrm{C}$ (squares) or $16^{\circ} \mathrm{C}$ (triangles) with kelp as food (solid symbols) or without food (open symbols). Sample size for each treatment group if $<10$ is given above data points

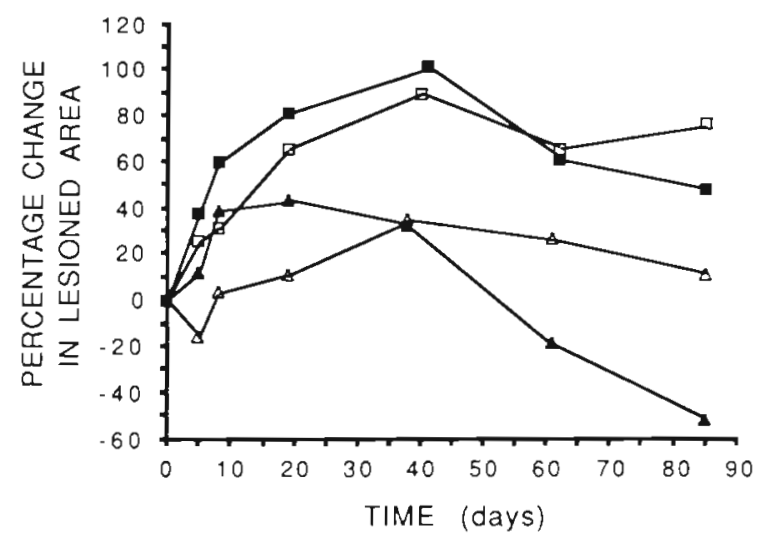

Fig. 6. Strongylocentrotus droebachiensis. Mean percentage change in lesioned area of experimentally abraded individuals over an $85 \mathrm{~d}$ period at $3^{\circ} \mathrm{C}$ (squares) and $16^{\circ} \mathrm{C}$ (triangles) with kelp as food (solid symbols) or without food (open symbols)

In all treatments, there was no measurable change in horizontal test diameter of individuals between the beginning and the end of the experiment. Righting 
times of individuals were lower at 16 than at $3^{\circ} \mathrm{C}$ but did not differ significantly between lesioned and control groups or fed and starved groups at each temperature ( $t$-test, $p>>0.05$ ). The only evidence of internal symptoms was discoloured gonads adjacent to the lesioned area in $17 \%$ of lesioned individuals that were starved at $16^{\circ} \mathrm{C}$

Unfed, field-collected individuals recovered in a similar manner as experimentally abraded individuals and the rate of spine regeneration was higher at 16 than at $3^{\circ} \mathrm{C}$ (Fig. 5b). In each temperature treatment 4 and 5 sea urchins died, most between 6 and $12 \mathrm{wk}$. Dead individuals generally were those with the largest lesions at the onset of the experiment.

\section{DISCUSSION}

\section{Lesion morphology}

Widespread epizootics have resulted in mass mortalities of sea urchins in various geographical areas (Maes \& Jangoux 1984, Scheibling 1984). Lesions of the body wall, with associated spine loss, have been a consistent overt symptom of disease during these events. Maes \& Jangoux (1984) attributed these mass mortalities to what they collectively term the 'bald-seaurchin disease' because of similarities in gross lesion morphology among various species of sea urchins

The lesions described here for Strongylocentrotus droebachiensis are generally similar to those reported for bald sea urchin disease (Maes \& Jangoux 1984, Maes et al. 1986). The lesioned area of test is devoid of external appendages (pedicellariae, tube feet and spines) and is usually separated from healthy test areas by a ridge of darkly pigmented, mucoid material. Scanning electron micrographs of lesions of S. droebachiensis (this study) and transmission electron micrographs of lesions of Psammechinus miliaris and P. lividus (Maes et al. 1986) indicate extensive breakdown of the stereom.

Lesions of Strongylocentrotus droebachiensis vary from nearly transparent (Stage 1) to purplish/black (Stage 2). In contrast, lesions of other sea urchins (Maes \& Jangoux 1984, Maes et al. 1986) have been described as areas of green necrotic tissue or denuded test skeleton surrounded by a belt of swollen reddish tissue. Differences in lesion colouration may be related to (1) differences in pigmentation among sea urchin species, (2) differences in associated microbial populations, or (3) varying concentrations of pigmented sea urchin defence cells. Red spherule cells, for example, circulate in the coelomic fluid and infiltrate sites of infection (Johnson 1969, Maes et al. 1986, Smith 1981). They contain a red echinochrome pigment which is bactericidal when released from the cell (Wardlaw \& Unkles 1978, Messer \& Wardlaw 1980, Service \& Wardlaw 1984).

Lesions of Strongylocentrotus droebachiensis are located predominantly on oral and lateral surfaces of the test., extending over both ambulacral and interambulacral areas. This is consistent with the distribution of lesions reported for other species (Maes \& Jangoux 1984 ) with the exception of $S$. purpuratus where lesions accurred exclusively in ambulacral areas (Johnson $1971 \mathrm{a})$

\section{Microbiota of lesions}

In Strongylocentrotus droebachiensis, several groups of Gram-negative bacteria, including Acinetobacter, Alcaligenes, Flavobacterium, Pseudomonas, and Enterobacteriaceae, were found both on lesioned and non-lesioned test surfaces. These bacteria may constitute a normal flora of the sea urchin. Since most marine bacteria are Gram-negative rods (Wood 1967), it is not surprising that they are also predominant on the sea urchin surface. Unkles (1977) found that Pseudomonas and Vibrio were the predominant normal flora of the sea urchin Echinus esculentus collected from the Clyde Sea area in Scotland, while Aeromonas, Flavobacterium, Acinetobacter and Moraxella occurred in lower numbers.

The increase in abundance of total bacteria in lesions of Strongylocentrotus droebachiensis compared to healthy test surfaces suggests that they may represent favourable sites for the proliferation of the normal flora. Acinetobacter, and to a lesser extent, Alcaligenes, may be particularly opportunistic types which can flourish on an injured test surface and predominate as the lesion progresses. The large variability in the abundance of Alcaligenes and Enterobacteriaceae among individual sea urchins may reflect successional changes in bacterial composition in the lesion.

Maes \& Jangoux (1985) isolated bacteria capable of causing lesions when innoculated onto artificially injured test areas of Paracentrotus lividus from Brittany, France, but did not identify the bacteria. Gilles \& Pearse (1986) isolated a total of 14 strains of bacteria of the genera Vibrio, Aeromonas, Flavobacterium and Pseudomonas from lesions of Strongylocentrotus purpuratus from California, USA. However, only 2 of these strains (Vibrio anguillarum and Aeromonas salmonicida) were capable of inducing lesions in abraded individuals and none of the induced lesions were fatal. In contrast to the findings of Gilles \& Pearse (1986), Vibrio species were rare to absent and Acinetobacter was the most abundant bacterial type found in lesions of $S$. droebachiensis. A common marine species, Acinetobacter calcoaceticus, can 
utilize calcium acetate as a sole energy source (Holt 1984). These bacteria may be responsible for the breakdown in the calcareous matrix of the sea urchin test. Differences in the microbial composition of lesions among sea urchin species may reflect species specific, seasonal and/or geographic differences in the normal microflora.

\section{Experimentally induced lesions}

A lesion produced by abrasion of the body wall of Strongylocentrotus droebachiensis is similar in gross morphology to a natural lesion and therefore considered to be a reliable analogue for laboratory study of lesion development and progression. Transmission experiments indicated that abrasion was in itself sufficient to induce lesions in healthy individuals, although lesion progression was accelerated, and recovery retarded, by innoculating an abraded area with lesion material from another individual. Sea urchins that were not abraded did not develop lesions indicating that injury of the epidermis, the barrier between the sea urchin and its environment, provided a route of infection. In nature, abrasion due to wave action or predation/cannibalism, may create a route of infection resulting in lesion development.

Previous studies also have shown that abrasion of the epidermis is necessary for lesion development in other sea urchins: Psammechinus miliaris (Maes \& Jangoux 1984) and Strongylocentrotus purpuratus (Gilles \& Pearse 1986). In these studies, however, characteristic lesions rarely developed unless injured areas of body wall were swabbed with lesion material. Gilles \& Pearse (1986) reported that a 'small red clot' formed over the abraded surface of $S$. purpuratus exposed to lesioned conspecifics, but did not consider this response as lesion formation. Moreover, these individuals recovered rapidly: regeneration of body tissues and spines was evident within $2 \mathrm{~d}$ and the abraded area was healed within 2 wk.

In the present study, the rate of recovery of lesioned areas was significantly higher at 16 than at $3^{\circ} \mathrm{C}\left(16^{\circ} \mathrm{C}\right.$ represents the maximal seawater temperature Strongylocentrotus droebachiensis normally experiences off Nova Scotia in the summer/fall; $3^{\circ} \mathrm{C}$ represents the average winter temperature). This may be due to a more effective host response (e.g. coelomocyte activation) at higher temperatures and/or to increased rates of cell production in regenerating tissues. Recovery also was more rapid in fed than in unfed individuals. In contrast, Schejbling \& Stephenson (1984) found that a high nutritional condition did not confer any resistance to amoebic infection of $S$. droebachiensis and that recovery from this disease occurred only at low tem- peratures $\left(<8^{\circ} \mathrm{C}\right)$; at temperatures $>12^{\circ} \mathrm{C}$ the disease is invariably lethal.

Initially, the lesions of all experimentally abraded individuals expanded in size regardless of temperature or food availability. After $12 \mathrm{wk}$, only fed sea urchins at $16^{\circ} \mathrm{C}$ showed a marked reduction in average lesion size to about $50 \%$ of the initial area. Complete regeneration of spines and tissues was not observed over the $12 \mathrm{wk}$ experimental period in any individual. Moreover, a few individuals died after their lesions expanded rapidly. In contrast, Maes \& Jangoux (1984) found that lesions of experimentally infected Psammechinus miliaris never extended beyond the abraded areas and healed completely within 3 to 4 mo (no temperature given). Similarly, Gilles \& Pearse (1986) tound that lesions of Strongyiocenisuius purpuratus healed completely within 3 mo at 15 to $16^{\circ} \mathrm{C}$. None of the sea urchins with experimentally induced lesions died in either of these studies. The higher recovery rates of sea urchins in these studies may be due to the smaller size of the experimental lesions: the initial abraded area was $1 \mathrm{~cm} \times 1 \mathrm{~cm}$ in Maes \& Jangoux's study, $0.3 \mathrm{~cm} \times 0.6 \mathrm{~cm}$ in Gilles \& Pearse's study and $1.5 \mathrm{~cm} \times 1.5 \mathrm{~cm}$ in our study.

The highest mortality rates were observed among unfed field-collected individuals, in which lesion size and stage of development were variable from the onset. Sea urchins which died had extensive lesions, some of which expanded rapidly during the course of the experimental period. Maes \& Jangoux (1985) found that, under laboratory conditions, death of Psammechinus miliaris only occurred when lesions extended over $>30 \%$ of the entire test surface or involved test perforation.

\section{Ecological significance}

The incidence of lesions in a healthy population of Strongylocentrotus droebachiensis off Nova Scotia was low (7\% of individuals) and the lesions on average were small ( 8 to $12 \%$ of the body surface). Lesions appear to be chronic infections from which $S$. droebachiensis can recover. Tissue and spine regeneration on lesioned test areas has been observed in fieldcollected sea urchins and in the laboratory (Scheibling \& Stephenson 1984). Extensive lesions undoubtedly result in impairment of locomotory, physiological (gas exchange, excretion) and sensory functions of the body wall. Scheibling \& Stephenson (1984) noted that sea urchins with lesions extending over more than $50 \%$ of the test were unable to right themselves when inverted. Infection also must impose some energetic drain which may be reflected by the high incidence of atrophied gonads and the lower gonad index recorded 
for lesioned individuals. Nevertheless, these infections are probably not an important cause of mortality.

In contrast, mass mortalities of Strongylocentrotus droebachiensis recently have occurred off Nova Scotia due to outbreaks of amoebic disease (Miller \& Colodey 1983, Scheibling 1984, 1986, Scheibling \& Stephenson 1984, Jones \& Scheibling 1985, Miller 1985). Symptoms of this disease include epidermal necrosis, extensive spine loss and red discoloration of tissues (Jones et al. 1985). Scheibling \& Stephenson (1984) noted a large proportion of lesioned individuals among the surviving population after an outbreak of this disease, and suggested that the lesions represented secondary infections. Although the lesions in some cases were extensive, there was no evidence of any further mortality and affected individuals appeared to gradually recover and regenerate their spines and tube feet.

Body wall lesions in sea urchins may be a general response to disruption of the epidermis due to abrasion (e.g. by predation or cannibalism) or some underlying pathogenic condition. The many accounts of sea urchin mass mortality, attributed to bald sea urchin disease based on similarities in lesion gross appearance (Maes \& Jangoux 1984), may actually have various causal agents. Further studies are required to elucidate specific pathogenic agents before generalities about chronic and acute diseases of sea urchins are made.

Acknowledgements. We thank Ms Betty Zwicker and Dr Michael Wiles for their advice given on microbial identification methodology and Bruce Raymond for assistance in data analysis. This research was supported by a Strategic Grant from the Natural Sciences and Engineering Research Council to R.E.S. and K. H. Mann.

\section{LITERATURE CITED}

Baross, J. A., Hanus, J, Morita, R. Y (1974). Effects of hydrostatic pressure on uracil uptake, ribonucleic acid synthesis and growth of three obligately psychrophilic marine vibrios, Vibrio alginolyticus, and Escherichia coli. In: Colwell, R. R., Morita, R. Y (eds.) Effects of the ocean environment on microbial activities. Proc. US-Japan Conf. Marine Microb., Univ. of Maryland, 1972. University Park Press, Baltimore, p. $180-202$

Bourdouresque, C. F., Nedelec, H. Sheperd, S. A. (1981). The decline of a population of the sea urchin Paracentrotus lividus in the Bay of Port-Cros (Var, France). Rapp. P.-v. Réun. Commn int. Explor. scient. Mer Méditerr 27: 223-224

Gibson, D. M., Hendrie, M. S., Houston, N. C., Hobbs, G. (1976). In: Skinner, F. A., Cox, J. B. (ed5.) Microbiology in agriculture, fisheries and food. Soc. Appl. Bacteriol. Symp. Ser. 4. Academic Press, New York, p. 135-159

Gilles, K., Pearse, J. S. (1986). Disease in sea urchins Strongylocentrotus purpuratus: experimental infection and bacterial virulence. Dis. aquat. Org. 1: 105-114
Hobaus, H., Fenaux, L., Hignette, M. (1981). Premieres observations sur les lesions provoquees par une maladie affectant le test des oursins en Mediterranee occidentale. Rapp. P.-v. Réun. Commn int. Explor scient. Mer Méditerr 27: 221-222

Holt, J. G. (1984). Bergey's manual of systematic bacteriology Williams and Wilkins, Baltimore

Johnson, P. T. (1969). The coelomic elements of sea urchins (Strongylocentrotus). 1 The normal coelomocytes: their morphology and dynamics in hanging drops. J. Invertebr. Pathol. 13: 25-41

Johnson, P. T (1971a). Studies on unhealthy appearing urchins from Whites Point. Kelp Habitat Improvement Project. Annual Report, 1970-1971. Calif. Inst. Technol. Pasadena, p. 55-69

Johnson, P. T (1971b). Studies on diseased urchins from Point Loma. Kelp Habitat Improvement Project. Annual Report, 1970-1971. Calif. Inst. Technol., Pasadena, p. 82-90

Jones, G. M., Scheibling, R. E. (1985). Paramoeba sp. (Amoebida, Paramoebidae) as the possible causative agent of sea urchin mass mortality in Nova Scotia. J. Parasit. 71. $559-565$

Jones, G. M., Hebda, A. J., Scheibling, R. E., Miller, R. J. (1985). Histopathology of the disease causing mass mortality in sea urchins (Strongylocentrotus droebachiensis) in Nova Scotia. J. Invertebr Pathol. 45: 260-271

Lessios, H. A., Robertson, D. R., Cubit, J. D. (1984). Spread of Diadema mass mortality through the Caribbean. Science 226: 335-337

Maes, P., Jangoux, M. (1984). The bald-sea-urchin disease: a biopathological approach. Helgoländer Meeresunters. 37: $217-224$

Maes, P., Jangoux, M. (1985). The bald-sea-urchin disease: a bacterial infection. Proc. 5th Intl Echinoderm Conf., Galway, 24-29 Sept., 1984, p. 313-314

Maes, P., Jangoux, M., Fenaux, L. (1986). La maladie de l' 'oursin-chauve' -ultrastructure des lesions et characterization de leur pigmentation. Annls Inst. océanogr., Paris 62 $37-45$

Messer, L. I., Wardlaw, A. C. (1980). Separation of coelomocytes of Echinus esculentus by density gradient centrifugation. In: Jangoux, M. (ed.), Echinoderms past and present. Proc. Eur. Colloq. Echinoderms, Brussels, 1979. A. A. Balkema, Rotterdam, p. 319-323

Miller, R. J. (1985). Succession in sea-urchin and seaweed abundance in Nova Scotia, Canada. Mar. Biol. 84: 275-286

Miller, R. J., Colodey, A. G. (1983). Widespread mass mortalities of the green sea urchin in Nova Scotia, Canada Mar. Biol. 73: 263-267

Pearse, J. S., Costa, D. P., Yellin, M. B., Agegian, C. R. (1977). Localized mass mortality of red sea urchin, Strongylocentrotus franciscanus, near Santa Cruz, California. Fish. Bull U.S. $75: 645-648$

Pearse, J. S., Hines, A. H. (1979). Expansion of a central California kelp forest following the mass mortality of sea urchins. Mar. Biol. 51. 83-91

Scheibling, R. E. (1984). Echinoids, epizootics and ecological stability in the rocky subtidal off Nova Scotia, Canada. Helgoländer Meeresunters. 37: 233-242

Scheibling, R. E. (1986). Increased macroalgal abundance following mass mortalities of sea urchins (Strongylocentrotus droebachiensis) along the Atlantic coast of Nova Scotia. Oecologia (Berl.) 68: 186-198

Scheibling, R. E., Stephenson, R. L. (1984). Mass mortality of Strongylocentrotus droebachiensis (Echinodermata Echinoidea) off Nova Scotia, Canada. Mar Biol. 78 153-164 
Service, M., Wardlaw, A. C. (1984). Echinochrome-A as a bactericidal substance in the coelomic fluid of Echinus esculentus (L.). Comp. Binchem. Physiol. 79B (2): 161-165

Smith, V J. (1981). The echinoderms. In: Ratcliffe, N. A., Rowley, A. F. (eds.) Invertebrate blood cells, Vol. 2. Academic Press, London, p. 513-563

Unkles, S. E. (1977). Bacterial flora of the sea urchin, Echinus esculentus. Appl environ. Microbiol. 34: 347-350
Walters, G. R., Plumb, J. A. (1978). Modified oxidation/fermentation medium for use in identification of bacterial fish pathogens. J. Fish. Res. Bd Can. 35: 1629-1630

Wardlaw, A. C., Unkles, S. E. (1978). Bactericidal activity of coelomic fluid from the sea urchin Echinus esculentus. J. Invertebr. Pathol. 32: 25-34

Wood, E. J. F. (1967). Microbiology of oceans and estuaries. Elsevier Publishing Company, New York

Responsible Subject Editor: Dr M. Jangoux; accepted for printing on March 14, 1988 